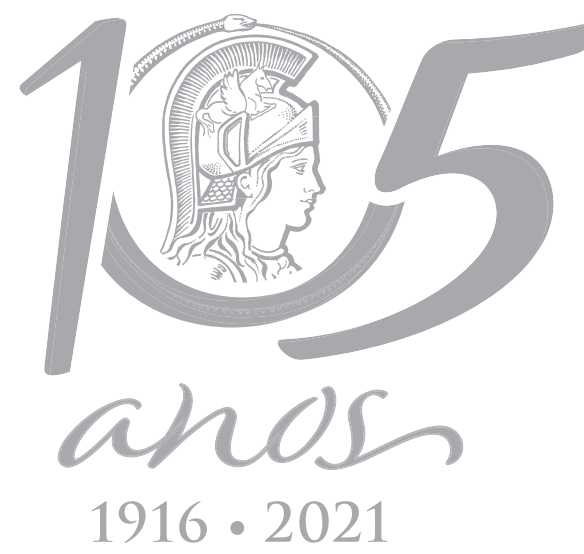

\title{
ECOSYSTEMS
}

\section{Proposal for the zoning of the industrial Brachyplatystoma vaillantii fisheries of the North Coast of Brazil and the influence of climatic factors on the fluctuations in the abundance of the species}

\author{
PAMELLA O. DA COSTA, IVAN F. JÚNIOR, EDUARDO T. PAES, FÁBIO C.P. PINHEIRO, \\ JÉSSICA A. DA SILVA, DEUSILENE C. DOS SANTOS \& ISRAEL H.A. CINTRA
}

\begin{abstract}
The present study was based on the analysis of 10,467 trawls of the industrial piramutaba (Brachyplatystoma vaillantii) fishing fleet of the Brazilian state of Pará, which were mapped by onboard GPS loggers (between February 2008 and September 2011) and the PREPS data from 40 vessels which were tracked by this system between 2008 and 2011. The variation in the mean monthly CPUE, based on Lomb's periodogram, revealed a well-defined and constant cycle with a duration of approximately one year. Three environmental factors influenced this cycle. The El Niño 3.4 index had a negative correlation with the CPUE of the piramutaba fishery, with a time lag of 15 months, while monthly rainfall and the mean discharge of the Amazon River correlated strongly ( $r=0.89$ and 0.87 , respectively; $p<0.001$ ) with the CPUE, with time lags of 12 and 11 months, respectively. The spatiotemporal analysis of the distribution of the activity of the piramutaba fishing fleet indicated that the most intense area of operation of the fleet lies between latitudes 00 - $\mathrm{N}$ and $02^{\circ} \mathrm{N}$, and longitudes 047040' W and 049040' W. This area was divided into four geographic quadrants, although fishery operations were concentrated in only three of these quadrants. The study proposed a quadrimester fishing cycle with zoning in three of the quadrants, where fishing would be permitted for four months (occupation period), followed by an 8-month rest period for the recuperation of stocks, aiming at the sustainability of this fishing exploration.
\end{abstract}

Key words: Amazon, fishery management, industrial fishing, PREPS vessel logging system.

\section{INTRODUCTION}

The fisheries on the north (Amazon) coast of Brazil include both artisanal and industrial fleets. Artisanal fishing is practiced using rudimentary equipment (lines, hooks, and nets made by the fishers themselves) and small boats, and its catches are destined for the local market or personal consumption. By contrast, the industrial fleets use sophisticated equipment (e.g., GPS, sonar, trawls, suction, and drift nets) and medium to large vessels, with its catches supplying national and international market (Diegues 1983, Dias-Neto \& Dornelles 1996, Frédou et al. 2009).

Brazil has favorable conditions for the expansion of fish productivity by both artisanal and industrial fleets, given its extensive coastline, of 8,500 km, and Exclusive Economic Zone (EEZ) of more than 4.3 million $\mathrm{km}^{2}$ (MPA 2012). The Brazilian EEZ extends from the 12 nautical mile limit of the nation's territorial waters, measured 
from the baseline used to define the continental shelf, to 200 nautical miles off the coast (SECIRM 2006).

According to Federal Law No. 8,617 of January 4th, 1993, Brazilian has sovereign rights over this exclusive zone for the exploration and exploitation, conservation and management of natural resources, living or non-living, the waters overlying the seabed, the seabed and its subsoil, and other activities for the exploitation of the area for economic purposes. The country also has exclusive rights for the regulation of scientific research, the protection and preservation of the marine environment, and the construction, operation, and use of all types of artificial island, facility, and structure. The most recent official statistics from the Ministry of Fisheries and Aquaculture on Brazilian extractive fishery production are for 2011, when the total catch was 803,270.2 t, which represents an increase of $2.3 \%$ in comparison with 2010. The production of the country's inland fisheries increased considerably 2009 and 2011, from $239,493 \mathrm{t}$ in 2009 to $248,911 \mathrm{t}$ in 2010 , and $249,600 \mathrm{t}$ in 2011. As a result, the contribution of these fisheries to the total extractive production increased from 29\% in 2009 to $31.1 \%$ in 2011 . The Brazilian North region contributed $55 \%$ of this catch, with 137,144.5 t of fish being produced in 2011 (MPA 2011).

The piramutaba, Brachyplatystoma vaillantii (Valenciennes in Cuvier \& Valenciennes 1840), is a catfish of the family Pimelodidae, and is the only freshwater pimelodid caught on an industrial scale, with a total catch of $24,789.3 \mathrm{t}$ in 2011, when it was second only to the curimatã (Prochilodus spp.), species of the family Prochilodontidae that had a catch of $28,647 \mathrm{t}$ in 2011.

Brachyplatystoma vaillantii is a demersal, migratory species with slow growth rates. The growth rings of $B$. vaillantii are formed annually (apparently, with two rings per year), and this fish may reach an age of 13.5 years. These catfish begin to breed at 3 years of age, when they are $42-64 \mathrm{~cm}$ in length, although commercial fisheries target individuals as young as 2 years of age (Barthem 1990, Pirker 2001, 2003). Excessive harvesting of young shoals may nevertheless expose piramutaba stocks to overfishing, by depleting these stocks before the individuals are large enough to contribute to the biomass by breeding (FAO 1997). These practices combined with a lack of monitoring and illegal fishing contribute to a drastic reduction in the availability of fishery resources. Clearly, it is becoming increasingly necessary to implement effective management measures to minimize these impacts.

The industrial piramutaba fisheries are based on pair or trail trawls, operating off the northern coast of Brazil at depths of less than 25 meters. These fisheries produce approximately $10.17 \%$ of Brazil's continental extractive fishery catch (Sanyo Techno Marine 1998, MPA 2010, 2011). This indicates that the the North region presents favorable conditions for the expansion of the fishery production chain, and this region is appropriate as a model for the development of the Piramutaba Trawl Fishing Zoning Plan.

In view of these favorable conditions in northern Brazil, we prepared a proposal for the zoning of the piramutaba (Brachyplatystoma vaillantii) trawl fisheries in this region. This was based on a spatiotemporal analysis of the PREPS (2011) (National Program for the Satellite Tracking of Fishing Vessels: Programa Nacional de Rastreamento de Embarcações Pesqueiras por Satélite) tracking data and onboard maps, with the primary objective of guaranteeing the biological sustainability of this fishery, as well as verifying the influence of climatic factors (flow, precipitation, El Niño, and La Niña) on catch volumes. This proposal will contribute 
to the development of the local fishing sector, and in particular, the sustainability of the resources targeted by this fishery.

\section{MATERIALS AND METHODS}

\section{Study area}

The study area is located in the coastal region of northern Brazil, which includes the states of Amapá, Pará and Maranhão (Figure 1), where the Brachyplatystoma vaillantii fishing grounds are found. The "piramutaba" is targeted in this region by the industrial trawling fleet, which also takes a number of other species as bycatch. The northern coast of Brazil is over 2,500 km long, and has a rainy climate, with annual precipitation of up to $3,500 \mathrm{~mm}$ (Isaac \& Braga 1999).

\section{Database}

The data used in the present study were obtained from two distinct, but related data sources, in both spatial and temporal terms, provided by the former Ministry of Fisheries and Aquaculture.

The two sources are the data from the onboard maps of the industrial trawler fleet of the Brazilian state of Pará and the PREPS (2011) (National Program for the Satellite Tracking of Fishing Vessels) database.

The PREPS data were used to produce density maps of the number of points of fishery activity within the study area between January 2008 and December 2011. The onboard maps provide information on trawls. A total of 10,467 trawls (pair or trail) of the piramutaba fishing vessels were analyzed between February 2008 and September 2011. The pair trawl system involves a pair of vessels which pull a single net simultaneously, while the trail method involves three vessels pulling two nets simultaneously (Mourão et al. 2007). The onboard map data were digitized and fed into a database using Excel.

The PREPS tracking method involves the remote monitoring of industrial-sized fishing

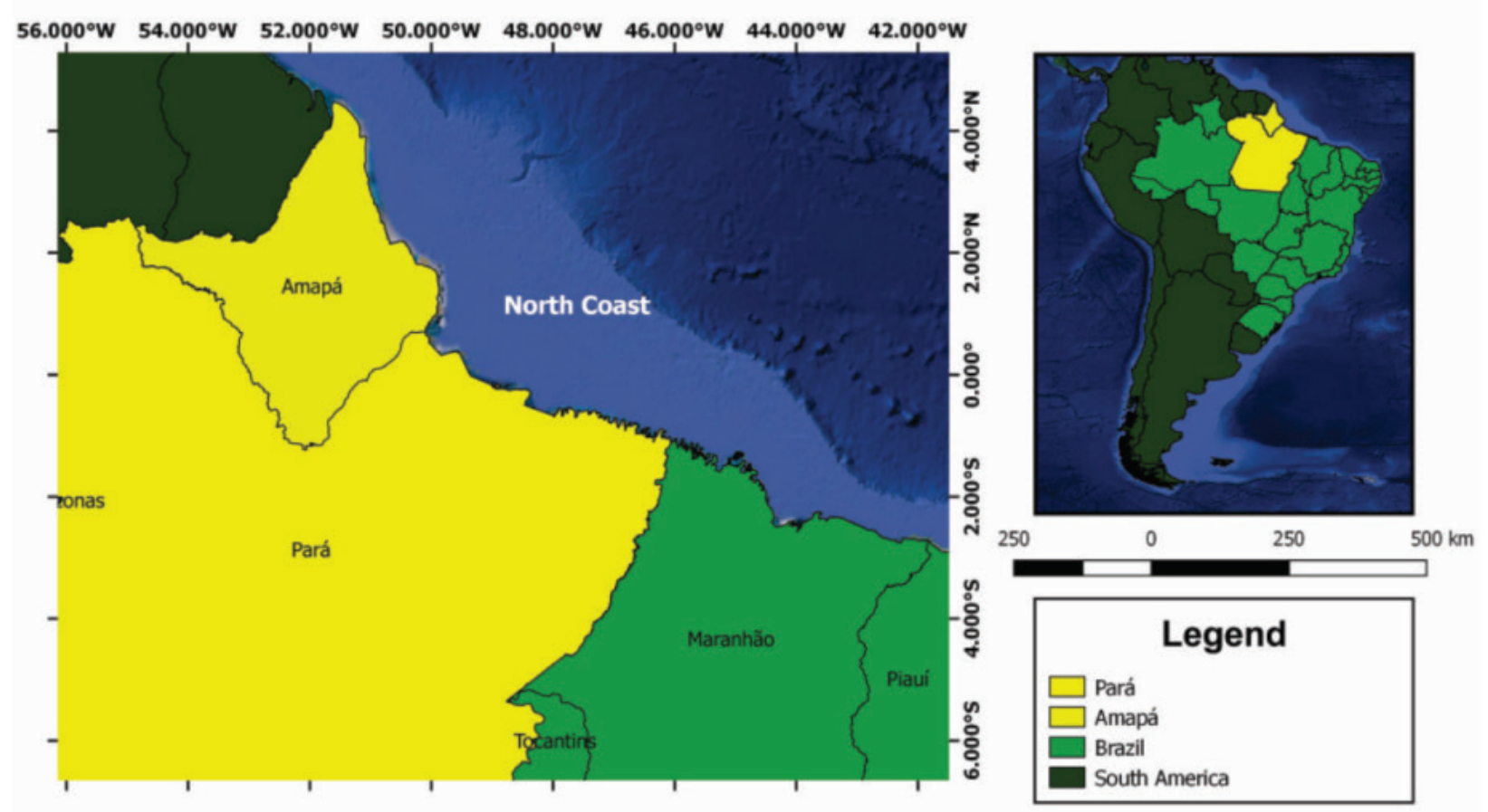

Figure 1. North Coast of Brazil (Amapá, Pará and Maranhão), highlighting the fishing area (Amapá-Pará) of the industrial fleet that captures the "piramutaba" (Brachyplatystoma vaillantii). 
vessels, which are at least $15 \mathrm{~m}$ long or weigh more than 50 tons gross tonnage (GT). A Global Positioning System (GPS) receiver installed on each vessel transmits a signal to the PREPS tracking center once an hour, providing geographic positioning data in the Datum WGS 84 and Universal Time Coordinated (UTC) systems (Zagaglia et al. 2009). As established in Normative Instruction no. 2 of 2006 of the SEAP/MMA/MD, the PREPS equipment consists of a GPS transmitter and receiver that transmits continuously, not only geographic positioning information, but also a set of information on the vessel: the identification of the vessel, universal date and time of each reading, the local depth.

The data on the flow (mean monthly discharge, in $\mathrm{m}^{3} / \mathrm{s}$ ) of the Amazon River were supplied from the gage at Óbidos, in Pará, obtained from the National Water Agency's (ANA) Hydrological Information System, HidroWeb (http://hidroweb.ana.gov.br/). The precipitation data $(\mathrm{mm})$ were based on the monthly average of the readings from the meteorological stations in northeastern Pará. Values for the El Niño 3.4 index were downloaded from the National Oceanic and Atmospheric Administration (NOAA) website, at https://www.esrl.noaa.gov/ psd/gcos_wgsp/Timeseries/Nino34/.

\section{Data treatment}

The PREPS data analysis was run monthly, then annually, to verify the spatiotemporal dynamics of the fisheries. The records of fishing activities during the closed season for the species were also analyzed. Normative Instruction no. 6, issued by the Brazilian Environment Ministry (MMA) in 2004 determines the piramutaba closed season between September 15th and November 30th of each year. Ordinance no. 11-N of SUDEPE (1987), which prohibits trawl fishing by motorized vessels less than 10 nautical miles off the north coast of Brazil, is also relevant here.

This ordinance also prohibits industrial fishery operation south of latitude $00005^{\prime} \mathrm{N}$ and west of the longitude $048^{\circ} 00^{\prime} \mathrm{W}$.

During the closed season, the vessels of the piramutaba fleet are temporarily allowed to harvest fish of other species at depths greater than $20 \mathrm{~m}$. In 2011, the beginning of the piramutaba closed season was postponed to October 1st, based on Interministerial Normative Instruction No. 11 of 2011.

The piramutaba trawling fleet of northern Brazil currently has 48 vessels (MMA 2004), although, in the the PREPS data (geographic coordinates, date and time) were obtained from 40 vessels authorized to trawl for piramutaba. These vessels operate in the region of the Amazon estuary at depths of 15-25 m, landing their catches primarily in the city of Belém in Pará (Haimovici \& Klippel 1999). A total of 1,979,305 data points were obtained between 2008 and 2011.

The data from the onboard maps provided information on the type of vessel (pair or trail), trawl duration (final decimal time - initial decimal time), and the volume (kg) of the catch per species. This information was processed and assembled in Excel. The CPUE values were obtained using the CPUE 1 index, which is the mean ratio of the catch to observed effort (Petrere-Júnior et al. 2010). The monthly variation of the CPUE 1 was plotted on a graph together with the standard errors. The monthly variation in the mean CPUE of the piramutaba fisheries of the north coast of Brazil was calculated as $\mathrm{kg} / \mathrm{hdec}$.net, where the catch is given in $\mathrm{kg}$ and the fishing effort in number of nets (1 or 2) used in each trawl multiplied by the duration of the trawl in decimal hours (hdec).

The CPUE was calculated for each trawl by: $C P U E=Y / f$, where $Y$ is the catch in $\mathrm{kg}$ and $f$ is the 
fishing effort in net-decimal hours. The onboard map data were processed to calculate the mean CPUE, standard deviation, and standard error. These data were compared in order to determine whether the CPUE tended to increaseordecrease among the annual cycles analyzed here. The nonparametric, sequential Mann-Kendall test (Mann 1945, Kendall 1975) was applied here to establish the significance of any observed trend. The seasonality in the CPUEs of the $B$. vaillantii time series was assessed using Lomb's periodogram analysis (Press et al. 1992). The significance of the periodicity found in this time series was tested against the null hypothesis of white noise. This technique is analogous to the Fourier transformation but is applied to unevenly sampled data (Press et al. 1992), and thus provides better results for this type of data than the Fourier transformation (Ruf 1999). The potential relationships between the mean CPUE and rainfall, the El Niño 3.4 index, and the discharge of the Amazon River were also verified using a cross-correlation analysis (Shumway \& Stoffer 2000). A cross-correlation analysis was used to assess whether the time series were significantly correlated with each other and to identify the existence of time lags between the series.

\section{Mapmaking}

The method used for the elaboration of the density maps was described by Zagaglia et al. (2009). The time difference (dT), distance between points $(\mathrm{dD})$, and mean speed of travel (Vel) were calculated between consecutive transmissions from the onboard tracking equipment. The Haversine equation (Sinnott 1984) was applied to calculate the linear distance between each pair of points, based on the latitude and longitude of these points and the diameter of the earth, which was used, in turn, calculate the velocity.
The speed patterns of the study vessels were identified considering three basic categories: that the displacement dynamics of vessels using a trawl during a cruise are basically: cruising, fishing, and mooring (speeds close to or equal to zero). The data on cruising and fishing were used to verify the compliance of the vessels with the environmental legislation, and to calculate the point density per month, and in the piramutaba closed season. The data were processed using the Kernel Density tool in the ArcGis environment, version 9.2, and aimed to identify of the principal fishing grounds used by the trawler fleet from the mapped density. Mooring records were excluded from the analysis.

\section{Fishery zoning}

The analyses described above will be used to define the most important areas for the piramutaba fisheries, which will be used to define exclusive fishing zones, in which the fleet will be authorized to operate only at a certain times of the year. This definition of exclusion zones aims to increase the profitability of fisheries, by restricting the access of vessels to specific areas, in a rotational system, without closing down the fisheries altogether. In a continuous system, the vessels have free access to the fishing grounds throughout the year, except during the closed season. In a rotational system, by contrast, the fishing zones are divided into quadrants, which alternate between periods of fishing and resting, rather than a complete shutdown of the fisheries. This system allows stocks to recuperate within the protected zones, which are defined here as a Rotating Protection Area.

The Rotating Protection Areas (RPA) will be divided into four quadrants. Each quadrant of an RPA represents approximately $25 \%$ of the total area. The definition of the quadrants will be based on the analysis of the PREPS data, which define the areas in which the fleet was most 
active during a given period. Trawling activity will be identified from the PREPS data according to the speed of the vessel, which is different when the vessel is cruising or searching for fish. Although using the speed of the vessel as a proxy for its operational status implies a certain potential for methodological error (i.e., the misidentification of its status), this problem appears to have been negligible, given the large amount of data on the trawling activity. Given this way, the method is considered to have been reliable for the purposes of the present study.

To implement a rotational fishing system, it is necessary to establish the fishing cycle, i.e., the occupation and rest periods to be adopted, and the freeways or "innocent passage" corridors for the transit of the vessels. This facilitates inventory management and ensures the better exploitation of the available space.

The occupation period (OP) is the time a vessel can operate in a quadrant in which fishing has been authorized. The OP will depend on the growth rate of the target species and other fishery resources available within the RPA. The duration of the OP must be compatible with the stocking rate. The longer the vessels remain in a quadrant, the greater the need for the control of stocks and infrastructure. In areas in which fish growth rates are high, then, the occupation and rest periods should be shorter.

In larger areas with smaller stocks, these periods may be extended, but they should never exceed the optimum limit. Rest areas are areas in which fishing is prohibited under any circumstances while stocks recover. One of the principal questions for the establishment of fishing and resting areas is the definition of the dimension of the areas. Rest areas located in the center of the system should occupy smaller quadrants, while those in more peripheral areas should be larger.
The fishery production in the different areas should be taken into account for the definition of the fishing and resting periods. Changes in the quadrants should be avoided as they may interrupt the recuperation of the stocks and lead to stock depletion. Quadrant degradation is an evolutionary process that involves a loss of vigor, productivity, and the natural resilience of that quadrant, which impedes the attainment of the production and quality levels necessary for it to be released for fishing. It is important to note that the zoning approach proposed in the present study is unprecedented, and that this proposal should be revised and updated according to the empirical results of the study.

\section{RESULTS AND DISCUSSION}

\section{Analysis of the data from the onboard maps}

A total of 10,467 trawls were processed between 2008 and 2011, of which 7,216 were pair trawls and 3,251 trail trawls. Trawls registered during the study period had a mean duration of 5.1 hours (range 1-8 h) and were divided into classes of two hours for analysis (Table I), through their respective percentages. Most of the trawls (56.41\%) lasted between 4.1 and 6 hours, while only $3.60 \%$ lasted less than 2 hours. The other two duration classes (2.1-4 and 6.1-8 hours) both accounted for around a fifth of the records. Mourão et al. (2007) also found that trawls for piramutaba typically lasted between 4 and 6 hours, while Barthem et al. (2015) recorded a mean duration of 3.4 hours (range 1.08-6.23 hours) in their study of piramutaba fishery management in the Amazonian estuary.

The standard error of the mean monthly CPUEs was also calculated (Figure 2). These data were treated using a pivot table to facilitate the analysis and comprehension of the information. In general, the standard errors of the mean CPUEs are relatively small, which supports the application of CPUE1 as an adequate estimate of 
Table I. Duration of the trawls conducted by the piramutaba (Brachyplatystoma vaillantii) trawler fleet operating off the north coast of Brazil, between 2008 and 2011, based on the onboard maps of the fishing vessels.

\begin{tabular}{|c|c|c|c|c|}
\hline Class & Duration (hours) & Number of samples & Mean duration & (\%) \\
\hline 1st & $1 \sim 2$ & 377 & 1.7 & 3.60 \\
\hline 2nd & $2.1 \sim 4$ & 2,284 & 3.5 & 21.82 \\
\hline 3rd & $4.1 \sim 6$ & 5,904 & 5.4 & 56.41 \\
\hline 4th & $6.1 \sim 8$ & 1,902 & 7.0 & 18.17 \\
\hline Total & & 10,467 & 5.1 & 100 \\
\hline
\end{tabular}

the relative abundance of the piramutaba, given that Petrere Junior et al. (2010) recommended the application of this parameter where the fleet is relatively homogeneous in terms of the size of the vessels and the duration of the fishery operations.

A total of 1897 piramutaba trawls were analyzed in 2008, with an annual mean CPUE of $174.33 \mathrm{~kg} / \mathrm{hdec}$.net. The highest CPUEs were recorded between May and September, with values of 336.03 (May), 340.06 (June), 327.61 (July), 315.16 (August), and 178.42 (September). In 2009, the mean CPUE for a total of 4958 trawls was $170.02 \mathrm{~kg} / \mathrm{hdec}$.net, with the highest CPUEs (202.75-298.26) being recorded between February and July. In 2010, a total of 3410 trawls were catalogued, with a mean annual CPUE of $177.17 \mathrm{~kg} / \mathrm{hdec}$.net, and the highest CPUEs being recorded during the first half of the year, ranging from 224.56 in January, 278.85 in April, and 252.83 in June, increasing to 324.88 in March and 327.16 in February, and peaking at 439.25 in May. In 2011, it was only possible to monitor 202 trawls, with records being obtained up to September. The mean CPUE for this period was $324.74 \mathrm{~kg} / \mathrm{hdec}$.net, with peak values being recorded in April (453.13) and July (367.00) (Supplementary Material - Table SI).

Clearly, the maximum productivity coincided primarily with the months of the first half of the year, while the lowest CPUEs were recorded mainly during the closed season (Figure 2). While the CPUE oscillated considerably among months, no significant temporal trend, reflecting either increasing or decreasing yields, was found across the four years analysed here (Mann-Kendall test: $Z=1.5677 ; p=0.1695)$. However, the observed pattern of oscillation was investigated further to elucidate the periodicity in the variation of the piramutaba CPUE over time. The spectral analysis using Lomb's periodogram (Press et al. 1992), where the power axis is given in units proportional to the sinusoids present in the data, showed that the highest peak of the spectrum had a frequency of 0.09191 (power $=11.7)$, a significant value $(p<0.001)$, with a periodicity of 10.87 months (Figure 3, arrow). However, other values were also significant power $=8.85 ; p$ $<0.01$ and power $=7.21, p<0.05$; red dotted lines in Figure 3), with a periodicity of between 10 and 12 months, indicating that the variation in the pyramidal CPUE reflected a well-defined and constant cycle of approximately one year. This is consistent with the study of Barthem (1990), who recorded annual growth, migration, and hydrological cycles in B. vaillantii.

Given the clear annual cycle in the yields of the piramutaba, the potential environmental factors that may determine this cycle were investigated. As a baseline hypothesis, given the fundamental role of the Amazon River in the distribution, abundance and recruitment of the piramutaba, changes in rainfall and the discharge of the river would be expected to influence the migration and predominance of these catfish on the north coast through the expansion of its niche during the flood period, and its retraction during low water. The climatic events include El Niño and La Niña, which modify rainfall patterns significantly in the 
Amazon basin (Marengo et al. 2008), causing extreme fluctuations in rainfall levels, which modify the timing and intensity of the flood pulse (Lin et al. 2017).

Precipitation and evapotranspiration patterns, and temperature are affected by both $\mathrm{El}$ Niño and La Niña events, in particular through the alteration of precipitation patterns (Moura et al. 2019). During La Niña events, the rainy season is more intense, with higher than normalprecipitation levels, while during El Niño events, the dry season is more intense, with less precipitation than normal. An additional question related to this hypothesis would be for how long one of these extreme weather events would influence precipitation patterns and river discharge, and, in turn, the productivity of the piramutaba of the the north coast. Matsunaga et al. (2017) analyzed the relationship between precipitation and river discharge on the north coast and the CPUE of the pirazutaba fishery through a production surplus model that incorporated these two factors, showing that the river flow contributed $56 \%$ of the variability in the CPUE, and precipitation, $46 \%$.

Based on these considerations, the mean piramutaba CPUE was correlated with El Niño index 3.4. (mean sea surface temperature anomalies in the equatorial Pacific), mean monthly rainfall $(\mathrm{mm})$, and mean monthly river discharge $\left(\mathrm{m}^{3} . \mathrm{s}^{-1}\right)$, with the latter two variables being relevant between February 2008 and December 2010. The cross-correlation between the mean piramutaba CPUE and El Niño 3.4 index was significantly negative $(r=-0.77 ; p<0.001)$, albeit with a time lag of 15 months. That is, after the index was lowest (negative anomalies in La Niña), which were recorded in early 2008, the piramutaba CPUE increased 15 months later, in the first half of 2009. Similarly, the peak in the index at the end of 2009 would correspond to the lowest CPUE values observed in the second half of 2010 (Figure 4). After peaking, the index declined sharply throughout 2010, resulting in an increase in the CPUE the following year, culminating in the peak observed in May 2011. It is important to note that, during the period of analysis of the CPUE (Figure 4), two La Niña events were detected, interspersed with an El Niño event, as well as periods when neither phenomenon was active (Moura et al. 2019).

The piramutaba CPUE was also correlated significantly with monthly rainfall $(r=0.89$; $p<0.001$ ), albeit with a 12-month time lag, that is, 12 month after an increase rainfall over the continent, there was an increase in CPUE on the coast. Similarly, there was a highly significant correlation $(r=0.87$; $p<0.001)$ between the CPUE and the mean discharge of the Amazon River, but once again, with a time lag of 11 months. This successive decrease in the time lag time between the variables and the CPUE was as expected, given the link between the different processes. The peaks in the piramutaba CPUE were preceded by peaks in rainfall and river discharge by 11-12 months, with extreme climatic events having an effect on a broader time scale (Figure 4). Overall, then, the piramutaba fishery was influenced positively by increases in rainfall and the outflow of the Amazon River, although the intensity of these processes is modulated, in turn, by La Ninã and El Niño. In La Niña years, in particular, the increase in rainfall and the associated increase in river discharge, had a positive effect on the piramutaba harvest on the northern coast of Brazil. The greatest peaks in the outflow of the Amazon River was recorded between May and June $2008\left(264 \mathrm{~m}^{3} . \mathrm{s}^{-1}\right)$, from April through July, in $2009\left(276 \mathrm{~m}^{3} \cdot \mathrm{s}^{-1}\right)$, and in May and June $2010\left(240 \mathrm{~m}^{3} . \mathrm{s}^{-1}\right)$. In 2008, the highest mean precipitation in Pará was recorded in March (432.1 mm) and April (396.2 mm). In 2009, the highest mean $(510.9 \mathrm{~mm})$ was recorded in May, while in 2010, it was recorded in April (383.8 mm) (Table SII). 


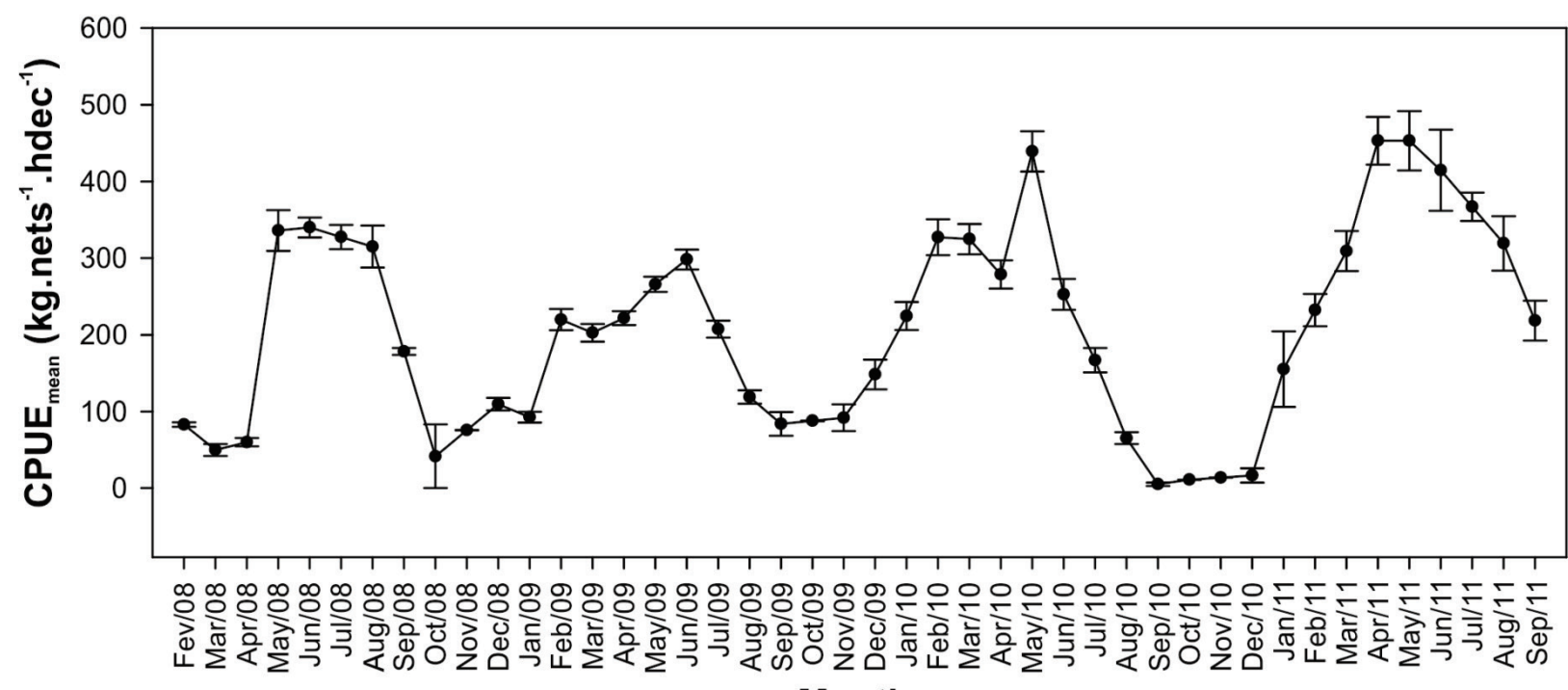

Months

Figure 2. Variation of CPUE 1 average per month of Brachyplatyatoma vaillantii, from February 2008 to September 2011.

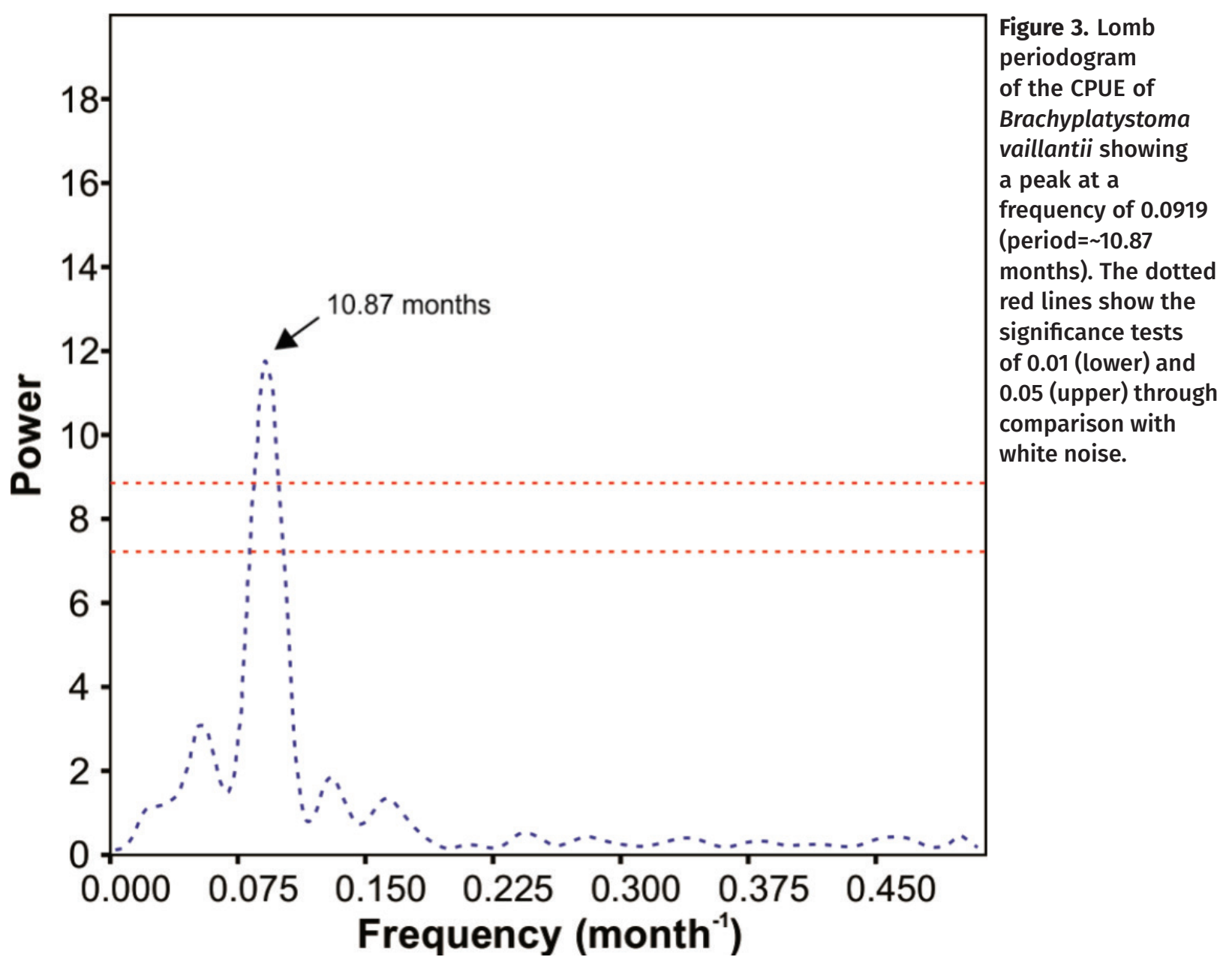




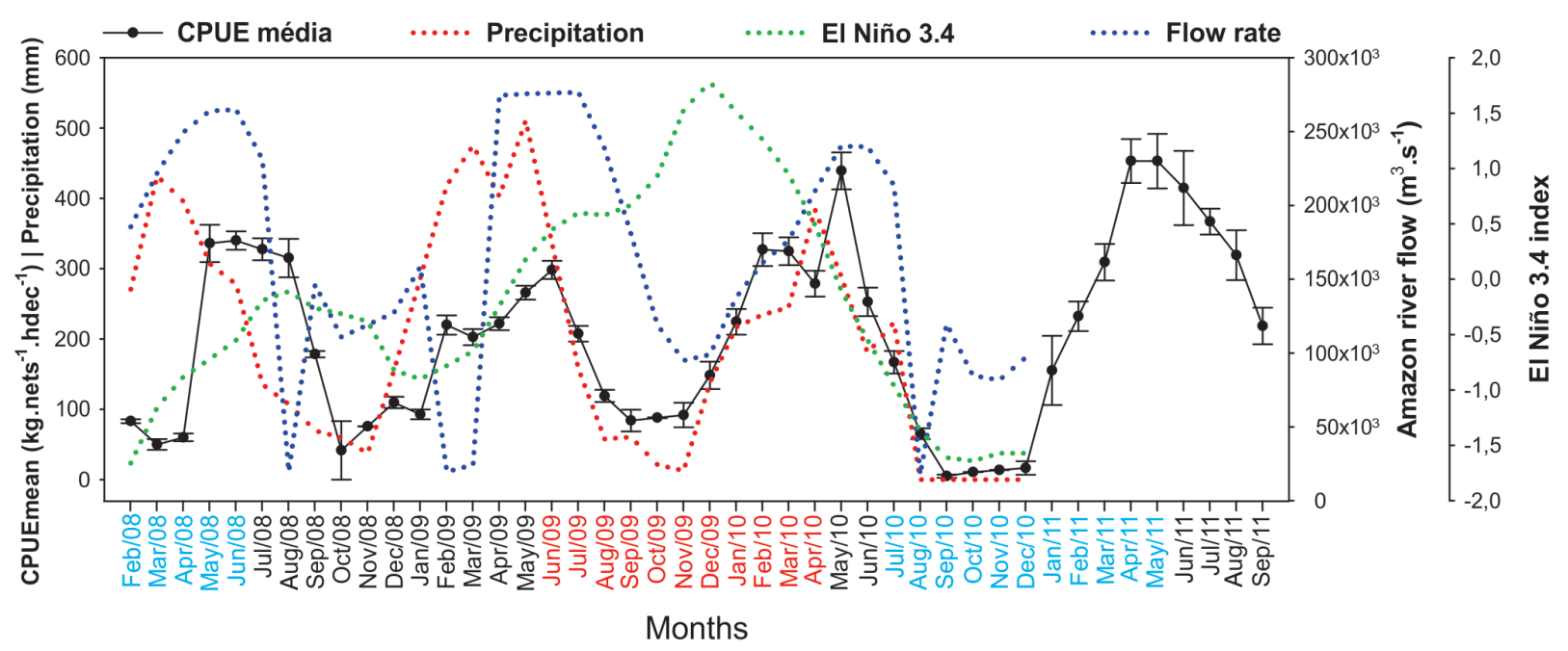

Figure 4. Variation 1 CPUE average per month B. vaillantii, El Nino index variation 3.4 along the time series and the variation of the average rainfall and the Amazon river flow along the time series. Months in blue = La Niña event; months in black = neutral; months in red = El Niño event.

\section{Preps data}

Geographic positioning data were obtained from 40 piramutaba fishing vessels between 2008 and 2011 (Table II). Relative density maps were prepared based on the 1,979,305 PREPS data points, covering both the normal fishing period and the closed season, in order to identify the principal areas in which the piramutaba fleet operates on the north coast of Brazil. The show clearly that the operations of the industrial pirmutaba fleet had a similar dynamic during each of the four years analyzed (Figures $5 a-d$ and $6 a-d$ ). During the fishing season, the fleet operates throughout the Amazon estuary (from the Amapá coast to the mouth of the Pará River). During the closed season, by contrast, it disperses to areas further from the coast and operated in a less concentrated pattern, due to the shutdown of vessels and the temporary authorisation for the harvesting of species other than B. vaillantii.

During both the $B$. vaillantii fishing season and the closed season, the vessels operate in the area between latitudes $00 . \mathrm{N}$ and $02^{\circ} \mathrm{N}$ and longitudes 047040' $\mathrm{W}$ and 049040' W. It is important to note here that, during both periods, the vessels operate within the natural breeding grounds of the estuaries of the Amazon and Para rivers (an area prohibited by SUDEPE ordinance no. 11 of 1987). Barthem et al. (2015) explained that ship masters have difficulty recognizing these areas, due to migration of sandbars or the inclusion of islands on the maps used for navigational calculations. Sandbars are highly dynamic (migrating at rates of 1.63-2.6 km.year ${ }^{-1}$ ) and the precision of the delimitation of these areas depends fundamentally on the accuracy of the available maps (Fernandes 2010).

The fishing zones were delimited based on the density of fishing records of the vessels, obtained by estimating the Kernel density. The darker red areas of the PREPS map indicate the highest relative density of $B$. vaillantii fishing activity during the respective period. The spatial distribution of the piramutaba fishing effort was used to delimit an RPA (rotating protection area), which was divided into four quadrants. The four quadrants have equal dimensions and are inserted between latitudes $00 \mathrm{O} \mathrm{N}$ and $02^{\circ} \mathrm{N}$ and longitudes 047040' W and 04940' W.

Monthly maps were then prepared for each study year to verify the fishing effort in 
each zone, in order to define the position of the quadrants and the zoning rotation. Based on the surface area of the relative density of fishing activity records collected between 2008 and 2011, it was possible to identify the principal fishing areas exploited by the piramutaba fleet on the north coast of Brazil in each month of the year (Figures 7, 8, 9, and 10). Based on these maps, the quadrants were numbered, and their geographical position was delimited within the RPA (Table III). The results of this analysis indicate that the 3rd quadrant defined for the zoning can be excluded from the rotary fishing system, given that no major concentrations of fishing activity was observed in this area, which was probably due to the fact that almost all of the area of this quadrant is more than 25 meters deep. Given this, the quadrant was defined as a corridor of innocent passage for the fishing vessels. This leaves quadrants 1, 2, and 4 for fishery zoning. The spatiotemporal analysis of the PREPS data for the pair trawling that operates off northern Brazil conducted by the Ministry of Fisheries and Agriculture for 2008 and 2009 revealed a fishing area of intense use, with three major concentrations of density in both years. This distribution pattern is in consistent with the results of the present study.

Overall, the results of the analysis of data on the B. vaillantii fisheries on the north coast of Brazil indicated a general pattern of a peak in the mean piramutaba CPUE during the period of greatest discharge of the Amazon River, declining during the closed season, and increasing immediately after this period, from December onward. These data are consistent with the spatiotemporal distribution of the PREPS data. During the peak of the Amazon discharge, the greatest fishing density was recorded in the 2 nd zoning quadrant, at the mouth of the Amazon River, off the coast of Amapá from 2008 to 2011. During the piramutaba closed season, the vessels were more active in the 4th zoning quadrant, from 2008 to 2011.

The spatiotemporal distribution of the fishing activity of the vessels tracked by PREPS shifts among the different periods of the year. To define the fishing cycle, the areas in which the fleet was most active during each period was identified, to determine the duration of the occupation and the rest period for each quadrant. Zoning rotation was defined following the monthly chronology of fishery activity, beginning in December of the previous year and continuing through the subsequent year. The analysis of the monthly pattern of occupation permitted the proposal of a quadrimester cycle in the three quadrants as follows (Figure 11):

- 1st quadrant: December, January, February, and March;

- 2nd quadrant: April, May, June, and July;

- 4th quadrant: August, September, October, and November.

This scheme allows for four months of fishing activity (occupation period) in each quadrant, followed by eight months of rest for stock recovery (this phase is reached at the end of the first annual revolving cycle). During the period when piramutaba fishing is permitted in the 1st quadrant, it will be prohibited in the 2nd and 4th quadrants, to allow the biomass to recover in these zones. At the end of this period, the cycle will be repeated, with fishing being permitted for four months in the 2nd quadrant and prohibited in the 1st and 4th quadrants. In the last quadrimester, fishing will be permitted in the 4th quadrant, and prohibited in the 1 st and 2 nd quadrants. In this scheme, each quadrant will be fished for four months and left to rest for stock recovery for eight continuous months over the annual rotational cycle. At the end of the year, the whole cycle should be repeated in the same order. 
Table II. Number of vessels tracked by PREPS between 2008 and 2011.

\begin{tabular}{|c|c|c|c|c|c|}
\hline & \multirow{2}{*}{ Months } & \multicolumn{4}{|c|}{ NUMBER OF VESSELS } \\
\hline & & 2008 & 2009 & 2010 & 2011 \\
\hline & January & 33 & 39 & 40 & 26 \\
\hline & February & 36 & 37 & 39 & 34 \\
\hline & March & 35 & 39 & 37 & 35 \\
\hline & April & 36 & 38 & 37 & 35 \\
\hline & May & 36 & 38 & 34 & 34 \\
\hline & June & 37 & 39 & 34 & 35 \\
\hline & July & 37 & 39 & 34 & 35 \\
\hline & August & 34 & 29 & 32 & 34 \\
\hline 亏 & September & 14 & 22 & 20 & 27 \\
\hline$\frac{n}{2}$ & October & 19 & 16 & 8 & 12 \\
\hline 은 & November & 14 & 25 & 15 & 11 \\
\hline & December & 38 & 37 & 21 & 28 \\
\hline
\end{tabular}

\section{CONCLUSIONS}

The analysis of climatic phenomena and their influence on fishery productivity was fundamental to the understanding of the fluctuations in the piramutaba catches over time. The PREPS data logging proved to be extremely useful for the characterization of fishing activities, providing important input for fishery planning through the real-time monitoring of fishing vessels, which provided accurate data on the geographical location of vessels. This approach to fishery zoning proved effective for the definition of the configuration of the zones and the resting areas, and should be considered as an option for the management of fisheries in general, including species other than $B$. vaillantii, with modifications to ensure the adequacy of the approach for each species or region. It is important to note that any zoning will not be permanent and should be evaluated annually and adjusted as necessary. These findings constitute an important potential tool for the development of effective regional environmental policies for the $B$. vaillantii fisheries of the north coast of Brazil. This should enable the state to both promote the development of these fisheries while also ensuring the quality of the environment, and the social and economic development of the region. 

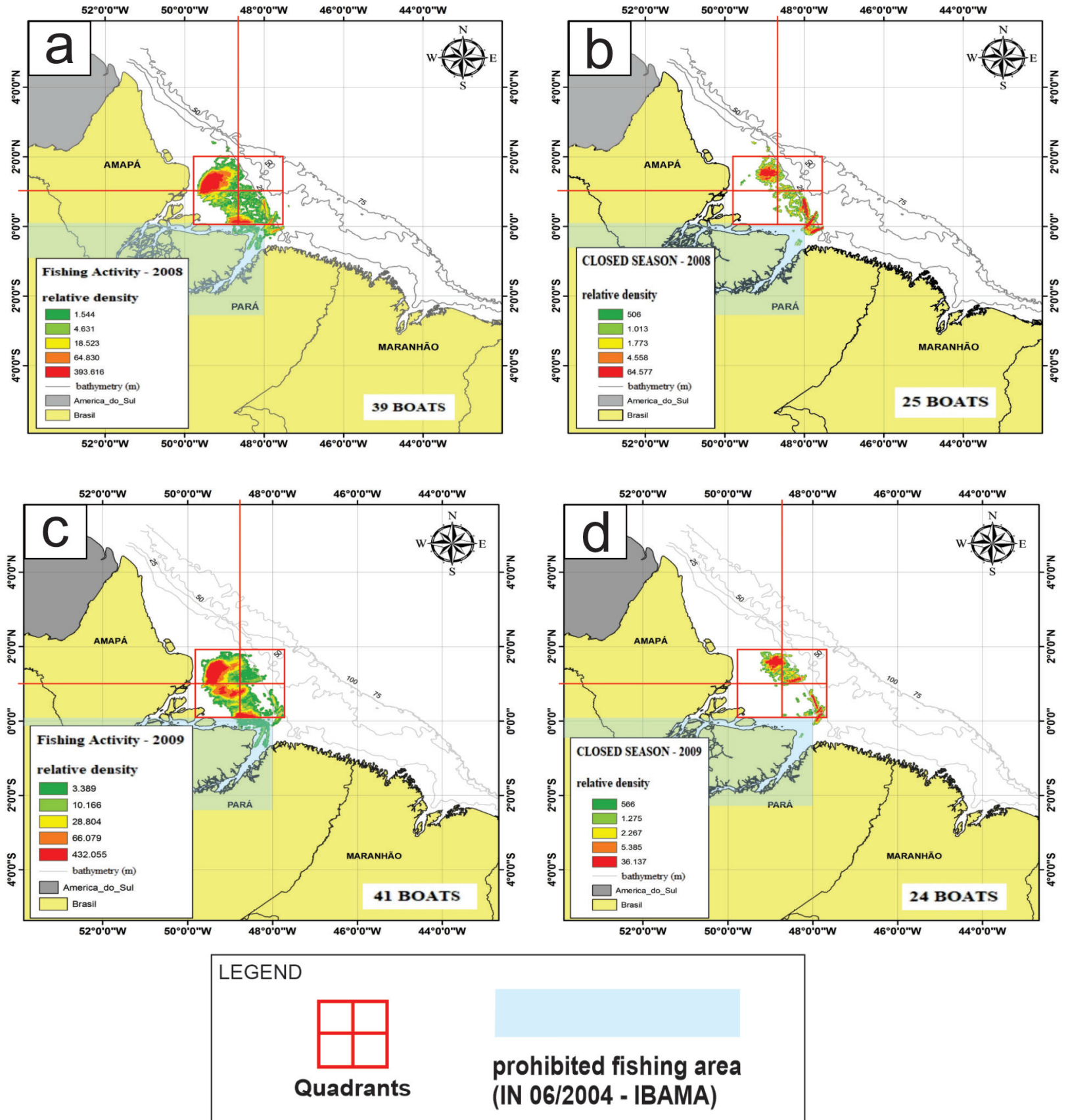

Figure 5. Dynamics of the industrial fleet capturing B. vaillantii and relative density of fishing activity from 2008 (Figures. $a$ and b) to 2009 (Figures. $c$ and d); in the normal period and in the species closure period. The segment outlined in red shows the total area within which the piramutaba trawling fleet operates. 

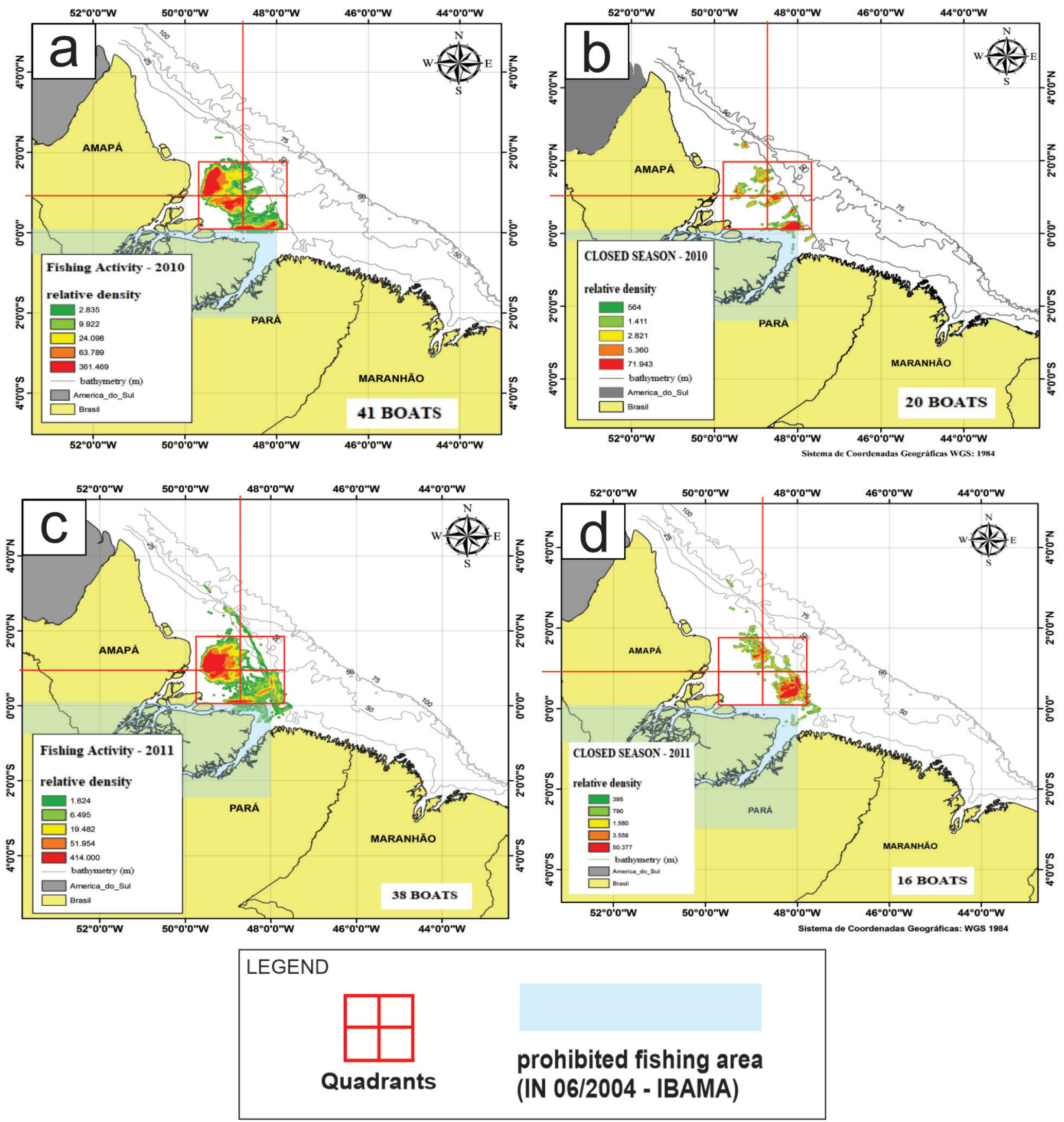

Figure 6. Dynamics of the industrial fleet capturing $B$. vaillantii and relative density of fishing activity from 2010 (Figures. $a$ and b) to 2011 (Figures $c$ and d); in the normal period and in the closed period of the species. The segment outlined in red shows the total area within which the piramutaba trawling fleet operates. 

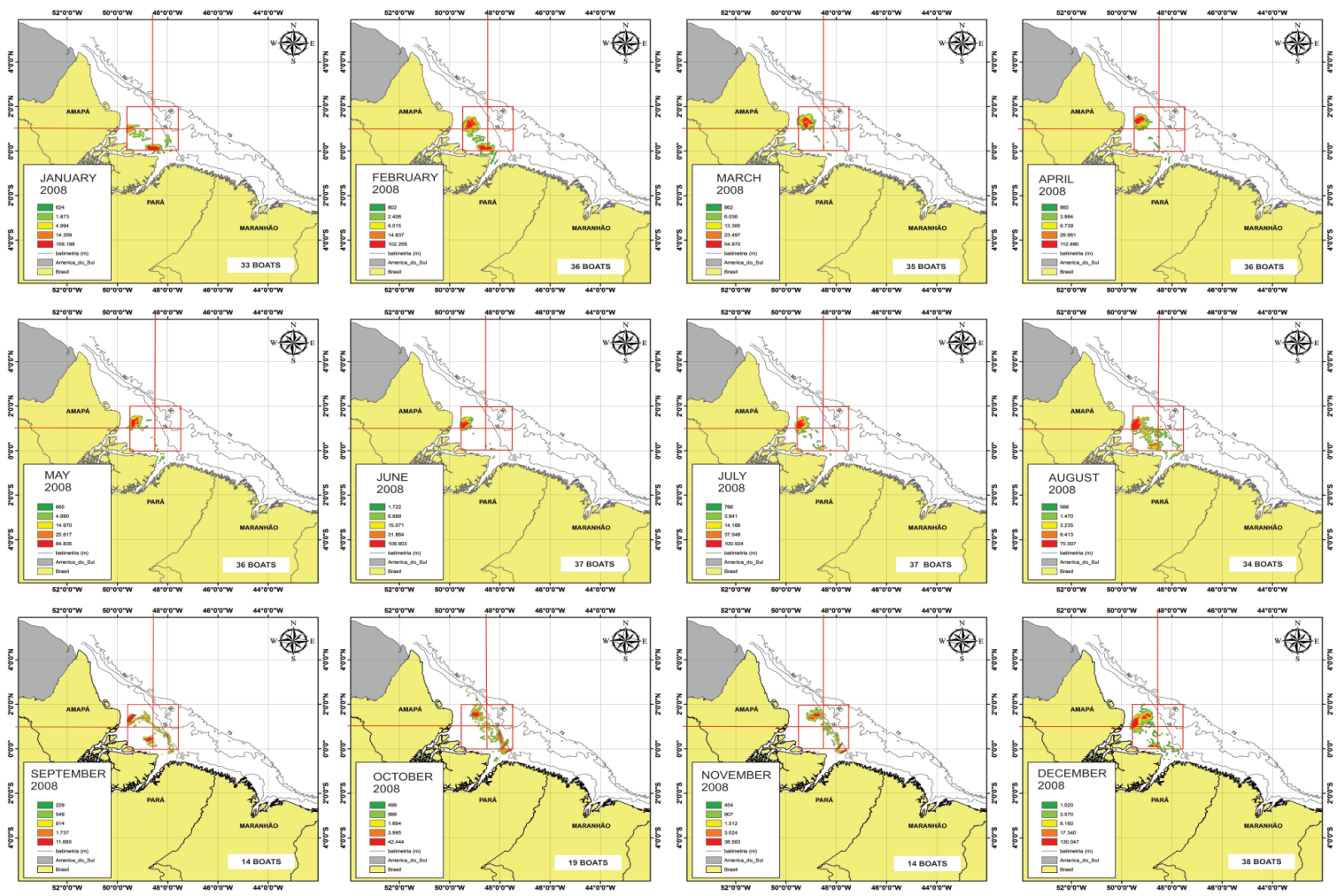

Figure 7. Relative density of fishing activity during the months of 2008 and fishing fleet dynamics divided by quadrant.
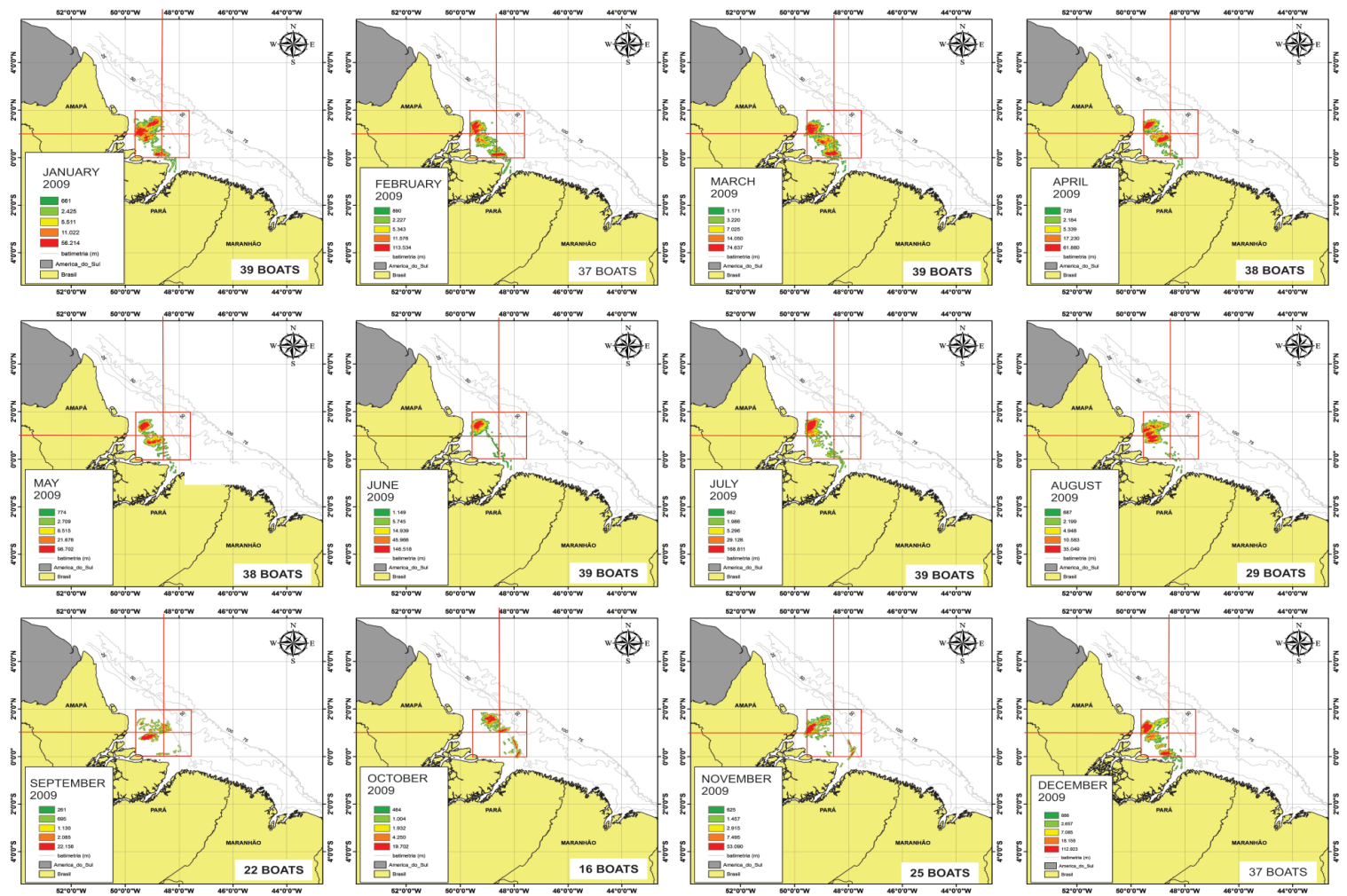

Figure 8. Relative density of fishing activity during the months of 2009 and fishing fleet dynamics divided by quadrant. 

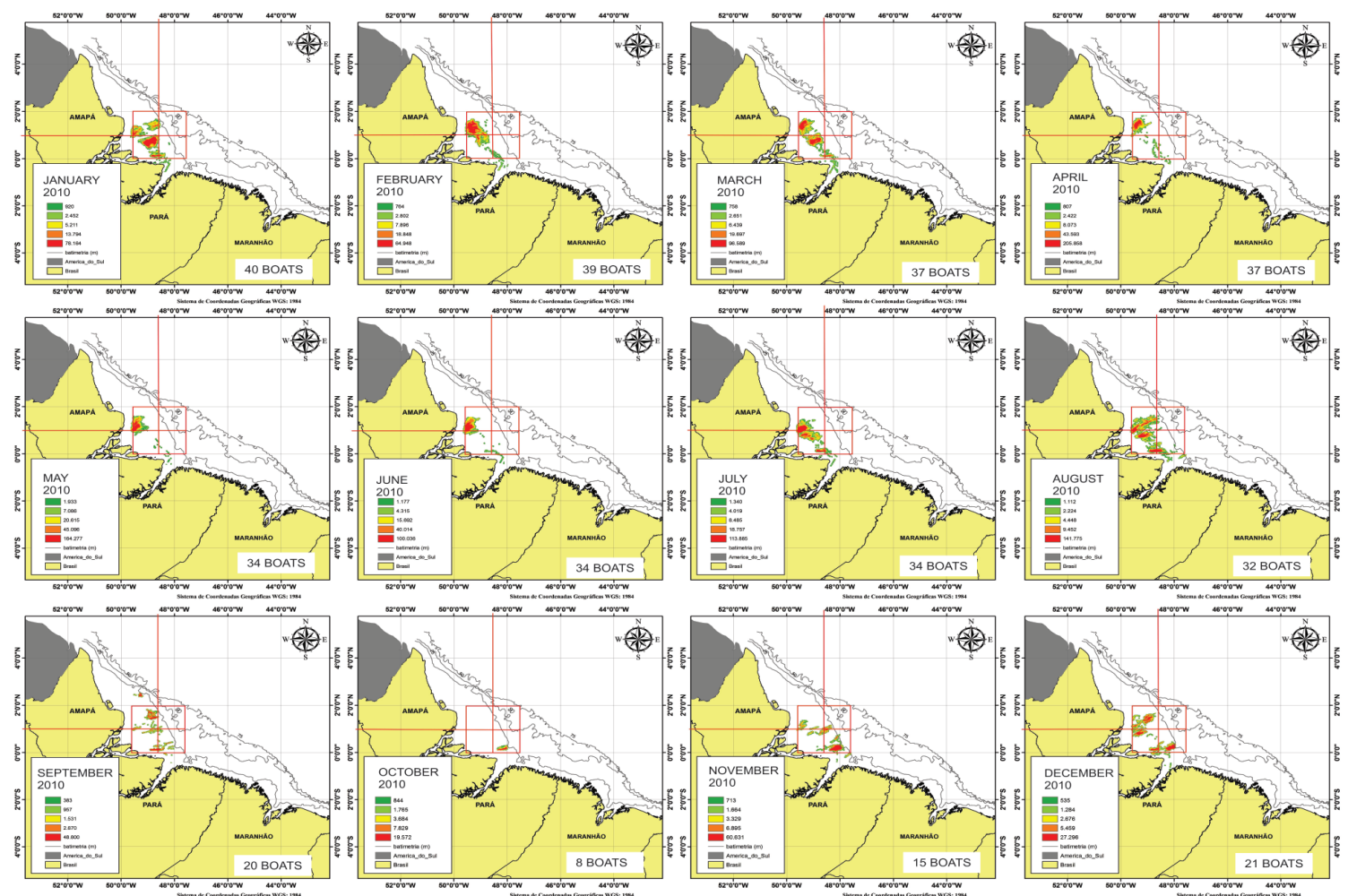

Figure 9. Relative density of fishing activity during the months of 2010 and fishing fleet dynamics divided by quadrant.
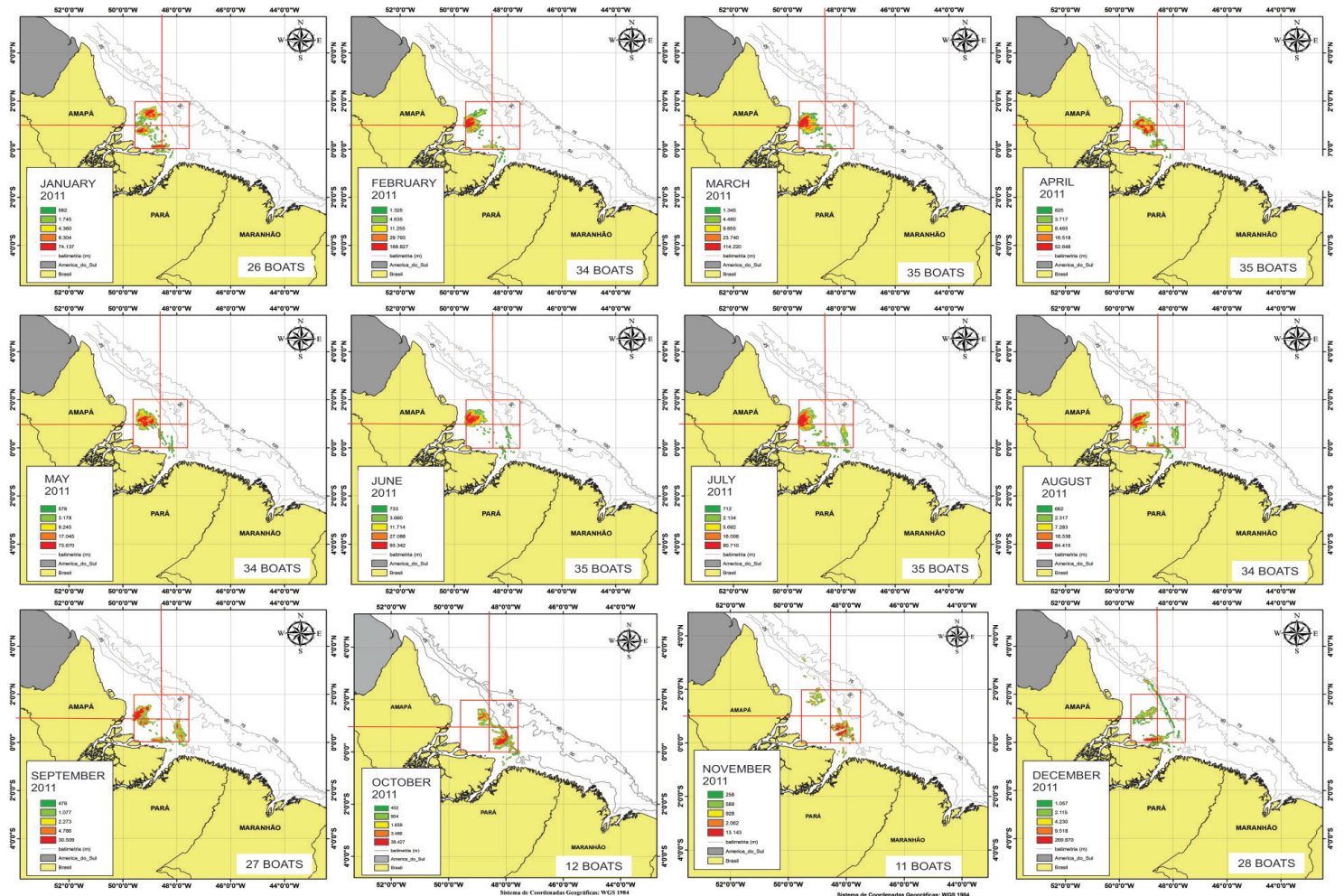

Figure 10. Relative density of fishing activity during the months of 2011 and fishing fleet dynamics divided by quadrant. 
Table III. Geographic coordinates of quadrants in the RPA zoning proposal, off the north coast of Brazil.

\begin{tabular}{|c|c|c|c|}
\hline Quadrant & Latitude & Longitude & Months \\
\hline 1 & $00^{\circ}-01^{\circ} \mathrm{N}$ & $048^{\circ} 40^{\prime}-049^{\circ} 40^{\prime} \mathrm{W}$ & December, January, February and March \\
\hline 2 & $01^{\circ}-02^{\circ} \mathrm{N}$ & $048^{\circ} 40^{\prime}-049^{\circ} 40^{\prime} \mathrm{W}$ & April, May, June and July \\
\hline 3 & $01^{\circ}-02^{\circ} \mathrm{N}$ & $047^{\circ} 40^{\prime}-048^{\circ} 40^{\prime} \mathrm{W}$ & innocent passage for vessels \\
\hline 4 & $00^{\circ}-01^{\circ} \mathrm{N}$ & $047^{\circ} 40^{\prime}-048^{\circ} 40^{\prime} \mathrm{W}$ & August, September, October and November \\
\hline
\end{tabular}

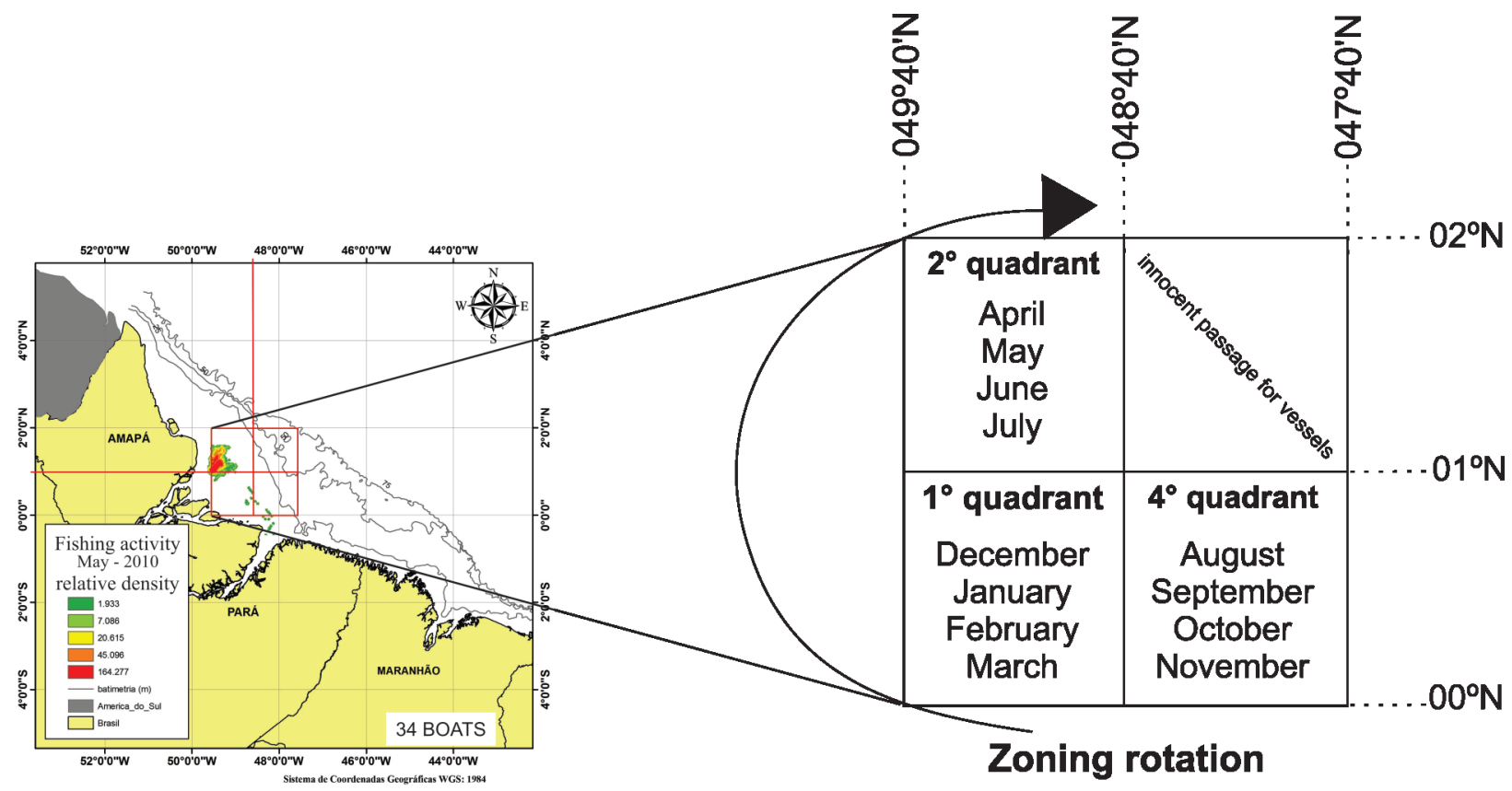

Figure 11. Schematic drawing of the proposed for the zoning of the industrial B. vaillantii fisheries of the North Coast of Brazil.

\section{Acknowledgments}

The authors would like to thank the Universidade Federal Rural da Amazônia (UFRA) for institutional support. The first author acknowledges the financial support of CAPES (Coordenação de Aperfeiçoamento de Pessoal de Nivel Superior), for a master's scholarship. We acknowledge the financial support of the Conselho Nacional de Desenvolvimento Científico e Tecnológico (CNPQ) and Secretaria de Aquicultura e Pesca (SAP) (Repensapesca Grant number 45806/2015-0).

\section{REFERENCES}

BARTHEM RB. 1990. Ecologia e pesca da Piramutaba (Brachyplatystoma vaillantii). Universidade Estadual de Campinas: Campinas, 268 p.
BARTHEM RB, MELLO-FILHO A, ASSUNÇÃO W, GOMES PFF \& BARBOSA CAC. 2015. Estrutura de tamanho e distribuição espacial da piramutaba (Brachyplatystoma vaillantii) na foz amazônica: implicações para o manejo da pesca. Bol Inst Pesca 41(2): 249-260.

CUVIER G \& VALENCIENNES A. 1840. Histoire Naturelle des Poissons. Tome 14, Pitois-Levrault, Paris, 464 p.

DIAS-NETO J \& DORNELLES LDC. 1996. Diagnóstico da pesca marítima no Brasil. Ibama: Brasília, 165 p.

DIEGUES ACS. 1983. Pescadores, camponeses e trabalhadores do mar. Ática: São Paulo, 287 p.

FAO. 1997. Documento Técnico sobre as Pescas. [http:// www.fao.org/3/W5448P/W5448P14.htm].

FERNANDES RD. 2010. Formação e Evolução dos Bancos de Areia da Foz do Rio Amazonas. Universidade Federal do Rio de Janeiro: Rio de Janeiro, 113 p. 
FRÉDOU FL, MOURÃO K, BARBOSA C, ALMEIDA O, RIVERO S \& THOMPSON R. 2009. Caracterização das pescarias industriais da costa norte do Brasil. Paper NAEA 237: 1-33.

HAIMOVICI M \& KLIPPEL S. 1999. Diagnóstico da Biodiversidade dos Peixes Teleósteos Demersais Marinhos and Estuarinos do Brasil. FURG: Rio Grande, 68 p.

ISAAC VJ \& BRAGA TMP. 1999. Rejeição de pescado nas pescarias da região Norte do Brasil. Arq Ciência Mar 32: 39-54.

KENDALL MG. 1975. Rank Correlation Methods, $4^{\text {th }}$ ed., London: CharlesGriffin, 202 p.

LIN H ET AL. 2017. Quantifying deforestation and forest degradation with thermaresponse. Sci Total Environ (607-608): 1286-1292.

MANN HB. 1945. Nonparametric tests against trend. Econometrica 13: 245-259.

MARENGO JA, NOBRE CA, TOMASELLA J, OYAMA MD, DE OLIVEIRA GS, DE OLIVEIRA R, CAMARGO H, ALVES LM \& BROWN IF. 2008. The drought of Amazonia in 2005. J Clim 21: 495-516.

MATSUNAGA AMF, FURTADO-JUNIOR I \& ITÓ LS. 2017. Análise quantitativa da influência de parâmetros ambientais sobre a captura por unidade de esforço (CPUE) da piramutaba brachyplatystoma vaillantii (Valenciennes, 1840) da costa amazônica do Brasil. Bol Téc Cient Cepnor 17(1): 9-19.

MMA - MINISTÉRIO DO MEIO AMBIENTE. 2004. Instrução normativa no 6, de 7 de junho de 2004. Estabelece o período de defeso para a pesca de arrasto de piramutaba (Brachyplatistoma vaillanti), limita a frota pesqueira que opera na captura de piramutaba e outros bagres (ordem Siluriforme) na Foz dos Rios Amazonas e Pará e dá outras providências. Diário Oficial da União, Brasília, 7 de junho de 2004, № 109, Seção 1, p. 81- 82. (MPA 2012). Boletim Estatístico da Pesca e Aquicultura - Brasil 2010. Brasil, Brasília, 128 p.

MOURA MM ET AL. 2019. Relation of El Niño and La Niña phenomena to precipitation, evapotranspiration and temperature in the Amazon basin. Sci Total Environ 651: 1639-1651.

MOURÃO KRM, PINHEIRO LA \& LUCENA F. 2007. Organização Social and Aspectos Técnicos da Atividade Pesqueira no Município de Vigia-PA. B Lab Hidro 20: 39-52.

MPA. 2010. Produção pesqueira e aquícola: estatística 2008 e 2009. Brasil: Brasília, 99 p. [http://www.icmbio. gov.br/cepsul/acervo-digital/37-download/estatistica].
MPA. 2011. Boletim Estatístico da Pesca e Aquicultura Brasil 2011. Brasil: Brasília, 60 p. [http://www.icmbio.gov. br/cepsul/acervo-digital/37-download/estatistica].

MPA. 2012. Boletim Estatístico da Pesca - Brasil 2010. Brasil: Brasília, 128 p. [http://www.icmbio.gov.br/cepsul/ acervo-digital/37-download/estatistica].

PETRERE-JÚNIOR M, GIACOMINI HC \& DE MARCO JÚNIOR P. 2010. Catch-per-unit effort: which estimator is best? Braz J Biol 70: 483-491.

PIRKER LEM. 2001. Determinação da idade and crescimento da piramutaba Brachyplatystoma vaillanti (Valenciennes, 1840) (Siluriformes: Pimelodadie) capturada no estuário amazônico. Universidade Federal do Pará: Belém, 107 p.

PIRKER LEM. 2003. Dinâmica populacional and o estado atual da exploração da piramutaba. In: Forsberg MC, Barroso A, Fabré NN, Pereira F and Cunha L(Eds), Seminário de apresentação de resultados: estudo estratégico do PROVARZEA: bases para o manejo da pesca dos grandes bagres migradores. Manaus: PROVARZEA/MMA/IBAMA/ PPG7, Amazonas, p. 13-15.

PREPS - PROGRAMA NACIONAL DE EMBARCAÇÕES PESQUEIRAS POR SATÉLITE. 2011. [https://www.preps.gov.br].

PRESS WH, TEUKOLSKY SA, VETTERLING WT \& FLANNERY BP. 1992. Numerical Recipes in C: The Art of Scientific Computing, $2^{\text {nd }}$ ed., Cambridge University Press: Cambridge, 735 p.

RUF T. 1999. The Lomb-Scargle periodogram in biological rhythm research: analysis of incomplete and unequally spaced time-series. Bio Rhythm Res 30(2): 178-201.

SANYO TECHNO MARINE. 1988. Draft final report for the fishery re-sources study of the Amazon and Tocantins river mouth areas in the federative republic of Brazil. Japão: Tokyo, 334 p.

SECIRM - SECRETARIA DA COMISSÃO INTERMINITERIAL PARA RECURSOS DO MAR. 2006. Marinha do Brasil. [http://www. sportnautica.com.br/amazonia_azul.html].

SHUMWAY RH \& STOFFER DS. 2000. Time Series Analysis and Its Applications, New York: Springer-Verlag, 596 p.

SINNOTT RW. 1984. Virtues of the Haversine. Sky Telesc 68(2): 159.

ZAGAGLIA CR, DOS SANTOS RC, BRICHTA M \& BARBOSA MG. 2009. Dinâmica espaço-temporal da Frota Pesqueira na Captura da Piramutaba com Rede de Arrasto no Estuário Amazônico com Base nos Dados do Programa Nacional de Rastreamento de Embarcações Pesqueiras 
por Satélite - PREPS. In: Anais XIV Simpósio Brasileiro de Sensoriamento Remoto. Natal: INPE, p. 4535-4542.

\section{SUPPLEMENTARY MATERIAL}

Tables SI-SII

\section{How to cite}

DA COSTA PO, JÚNIOR IF, PAES ET, PINHEIRO FCP, DA SILVA JA, DOS SANTOS DC \& CINTRA IHA. 2021. Proposal for the zoning of the industrial Brachyplatystoma vaillantii fisheries of the North Coast of Brazil and the influence of climatic factors on the fluctuations in the abundance of the species. An Acad Bras Cienc 94: e20191320. DOI 10.1590/00013765202120191320.

Manuscript received on October 28, 2019;

accepted for publication on February 02, 2021

\section{PAMELLA O. DA COSTA ${ }^{1}$}

https://orcid.org/0000-0002-1860-2101

\section{IVAN F. JÚNIOR ${ }^{2,3}$}

https://orcid.org/0000-0002-0127-0171

\section{EDUARDO T. PAES ${ }^{2}$}

https://orcid.org/0000-0002-9429-2598

\section{FÁBIO C.P. RIBEIRO ${ }^{2}$}

https://orcid.org/0000-0001-7788-1035

\section{JÉSSICA A. DA SILVA}

https://orcid.org/0000-0003-3150-8029

\section{DEUSILENE C. DOS SANTOS ${ }^{1}$}

https://orcid.org/0000-0002-8708-9655

ISRAEL H.A. CINTRA ${ }^{2}$

https://orcid.org/0000-0001-5822-454X
${ }^{1}$ Universidade Federal Rural da Amazônia, Avenida Presidente Tancredo Neves, 2501, 66077-830 Belém, PA, Brazil

${ }^{2}$ Universidade Federal Rural da Amazônia, Instituto

Socioambiental e dos Recursos Hídricos, Avenida Presidente

Tancredo Neves, 2501, 66077-830 Belém, PA, Brazil

${ }^{3}$ Universidade Federal Rural da Amazônia, Laboratório de Prospecção e Estatística Pesqueira, Avenida Presidente

Tancredo Neves, 2501, 66077-830 Belém, PA, Brazil

\section{Correspondence to: Pamella Oliveira da Costa}

E-mail:pamellaocosta@yahoo.com.br

\section{Author contributions}

Each author presented a relevant contribution to the elaboration of the present manuscript, as follows: MSc. Pamella Costa: prepared and wrote the manuscript, processed the data, produced the maps and tables, contributed to the analysis of the results and the discussion, and reviewed the manuscript; Dr. Ivan Furtado: prepared the methods and abstract, contributed to the analysis of the data and the results, and was the principal contributor to the final text; Dr. Eduardo Paes: compilation of the database, analysis of the data and the results; Dr. Fábio Pamplona: produced the graphs and contributed to the results and discussion; MSc. Jéssica Almeida: Contributed to the Introduction and the preparation of the data and the maps; MSc. Deusilene dos Santos: Introduction and contributed to the preparation of the data and the maps; Dr. Israel Cintra: revised and supervised the development of the manuscript.

(cc) BY 